\title{
UNITARY BOARDS AND MUTUAL FUND GOVERNANCE
}

\author{
Sophie Xiaofei Kong \\ Western Washington University \\ Dragon Yongjun Tang \\ University of Hong Kong
}

\begin{abstract}
A unique governance structure for mutual funds is unitary board - one board overseeing all funds in the entire family. We find strong evidence for unitary board as an effective governance mechanism. Funds with unitary boards are associated with lower fees, are more likely to pass the economies of scale benefits to investors, are less likely to be involved in trading scandals, and rank higher on stewardship. In contrast, funds with larger or more independent boards charge higher fees and rank lower on stewardship. Our findings indicate that unitary boards of small size, rather than independent boards, may be more beneficial to fund shareholders.
\end{abstract}

JEL Classification: G2, G3

\section{Introduction}

Each U.S. mutual fund is required to have its own board of directors (separate from the board of directors for the fund management company). Although each fund can choose its own individual board, one unique feature of mutual fund governance is the frequent use of unitary board: one board overseeing all funds in the entire fund family. A unitary board is an extreme case of interlocking directorate; that is, the same director sits on different boards. In this article, we empirically examine the role played by a unitary board in mutual fund governance. Our study sheds light on the understanding of fund governance and the current debate on fund governance regulations.

We thank Gerald Gay (the editor), an anonymous referee, Renee Adams, Keith Brown, Sean Collins, Ann Gillette, John Griffin, Jay Hartzell, Eric Higgins, John Hund, Bob Parrino, Shisheng Qu, Laura Starks, Sheridan Titman, Kelsey Wei, Fei Xie, Hong Yan, and seminar and conference participants at University of Texas at Austin, Kansas State University, Western Washington University, CCRG SEC Financial Reporting and Governance Conference, Eastern Finance Association annual meeting, Vanderbilt University Conference on Conflicts of Interest in Financial Markets, and Financial Intermediation Research Society (FIRS) conference in Shanghai for helpful discussions and useful comments. We also thank the Eastern Finance Association for the Best Paper in Financial Intermediation Award. Part of the work was done when Tang was at Kennesaw State University. 
Mutual funds are a widely used investment vehicle. ${ }^{1}$ Protecting fund shareholders' interests becomes crucial to cultivating public confidence in the domestic investment industry. However, recent mutual fund scandals such as late trading and market timing show that mutual fund investors have not been treated properly. To restore public trust in the mutual fund industry, the Securities and Exchange Commission (SEC) launched a major campaign to strengthen mutual fund governance. On June 23, 2004, the SEC passed a rule requiring every mutual fund board have an independent chairman and at least $75 \%$ independent directors. This rule has spurred fierce debate regarding its validity. The imposed regulation on mutual fund governance is controversial because of the lack of theoretical and empirical evidence on mutual fund governance. In this article, we move beyond the overly stressed debate on director independence and explore an alternative governance mechanism: unitary board.

Unitary boards are a unique governance mechanism for the mutual fund industry. Their role in mutual fund governance is particularly interesting because other conventional governance mechanisms available to industrial corporations are nearly nonexistent for mutual funds. Hostile takeovers are rare in the mutual fund industry. Reduction of agency conflicts through competition among fund advisers may also be limited because mutual funds offered by different fund advisers are often viewed as different products. Mutual fund ownership is substantially more dispersed than industrial firm ownership. Blockholders are few and silent. Monitoring from other stakeholders such as debtholders is absent. Therefore, unitary boards may be a potentially important substitute for alternative governance mechanisms.

Unitary board structure has two potential advantages over multiple board structure: enhancing information sharing among funds and improving bargaining power of mutual fund boards against fund management companies. Unitary board structure can be thought of as the family strategy for fund shareholders across funds. Applying the consensus-building model of Caillaud and Tirole (2007) to the mutual fund context, we infer that fund advisers may benefit from ambiguity among board members' views toward proposals from fund advisers. Enhanced information sharing will facilitate communication among board members and reduce the ambiguity. A unitary board representing all funds in the fund family may also have more bargaining power against fund advisers and other service providers because the stake is bigger. In addition, a unitary board enables management companies to share costs among different funds and to realize economies of scale including director compensation. Finally, a unitary board can better evaluate the overall benefits

\footnotetext{
${ }^{1}$ According to the Investment Company Institute (ICI) 2006 Mutual Fund Fact Book, an estimated 91 million individuals in 54 million (48\%) U.S. households owned mutual funds in 2005. On average, $10.5 \%$ (6.4\%) of U.S. households' financial (total) assets is in mutual funds at the end of 2005, according to Flow of Funds Accounts of United States released by Board of Governors of the Federal Reserve System.
} 
resulting from economies of scale and demand advisory contracts more favorable to fund investors. ${ }^{2}$

There are also concerns involving unitary boards. First, unitary boards may exacerbate board directors' career concerns because directors on unitary boards are generally compensated higher and fund advisers select board directors for new funds. Board directors may yield to fund managers to keep their board seats. However, the effect of fund directors' career concerns is arguably limited because fund directorship is a part-time job and most directors are wealthy individuals. ${ }^{3}$ Second, the workload may be excessive for directors on unitary boards, especially if the fund family consists of a large number of funds. Nevertheless, director responsibilities are largely repetitive in nature and skills and knowledge learned from overseeing one fund can be easily transferred to other funds in the same family. This alleviates the workload concern. Overall, we expect the benefits of unitary boards to overweigh the costs.

We empirically test whether a unitary board can significantly improve the interests of fund investors through lower fees and improved director stewardship, controlling for other governance mechanisms such as board independence, board size, and independent director incentive (the percentage of independent directors whose investments in the fund family are greater than the minimum of their annual compensation or $\$ 100,000)$. We manually collected mutual fund board data for 969 large U.S. mutual funds offered by 126 fund families for which the recently released Morningstar stewardship rating is available for 2003, the year before the 2004 mutual fund governance regulations. These funds have a total of $\$ 2.6$ trillion in assets as of the end of 2003, which accounts for 35\% of the $\$ 7.4$ trillion assets of the entire U.S. open-end mutual fund industry. The total net asset value from the 126 fund families aggregates to $\$ 5.1$ trillion, roughly $69 \%$ of the overall fund market. We then merge the fund board data with the Survivorship-Free Mutual Fund database from the Center for Research in Security Prices (CRSP) to obtain other fund and board information.

After compiling the data, we examine the effectiveness of internal governance mechanisms, particularly unitary boards. The focus of our discussion is on direct measures of investor interests such as fees, performance, and flows. Moreover, we consider auxiliary measures of governance effectiveness to strengthen the plausibility of our findings. Specifically, we study how governance mechanisms alleviate agency conflicts, as reflected by director performance and manager

\footnotetext{
${ }^{2}$ Regarding the relative importance of these two advantages, Baranchuk and Dybvig (Forthcoming) show that, in a diverse board, new information brought in by directors may be more important than director's bargaining impact.

${ }^{3}$ According to Management Practice Inc., independent directors' compensation from serving on mutual fund boards is less than one-fifth of their annual income for directors who are still employed, and less than one-tenth of their liquid wealth for directors who have retired.
} 
involvement in trading scandals. We find that in our sample, unitary board structure helps promote fund shareholders' interests, improve director stewardship, and deter managerial misbehavior. More specifically, in 2003, overall annual cost for funds overseen by unitary boards was 31 basis points (bps) lower than funds overseen by alternative board structure. Funds with unitary boards rank significantly higher with Morningstar's stewardship grades. Moreover, funds governed by unitary boards are less likely to be implicated in the late trading and market timing scandals. In contrast, funds with more independent boards are associated with higher fees and lower Morningstar's stewardship grades. We confirm the finding in previous studies that larger boards are less efficient. The results in the study indicate that the current fund governance reform should place more emphasis on directorate interlocking and board size than board independence.

Our work focuses on the effect of unitary board and deviates from the current discussion on board independence. However, our findings on other governance variables are mostly consistent with other contemporaneous work. The studies most closely related to ours are Ferris and Yan (2007a, 2007b), Meschke (2007), and Qian (2006). Ferris and Yan (2007b) investigate the effects of unexplained director compensation and presence of pricing committee, in addition to board independence and other governance variables, on fund scandal implication and fees. Meschke explores the determinants of board structure and their effects on fund fees and performance. Qian discusses the effectiveness of fund flows as an external fund governance mechanism. Our innovations are using the director performance data in Morningstar's stewardship grades and examining the role played by unitary board in mutual fund governance.

Our work adds to the current discussions on mutual fund governance (Tufano and Sevick 1997; Del Guercio, Dann, and Partch 2003; Zitzewitz 2003; Chen, Goldstein, and Jiang Forthcoming; Cremers et al. Forthcoming; Ding and Wermers 2006; Ferris and Yan 2007b; Meschke 2007; Qian 2006; Khorana, Tufano, and Wedge 2007; Wellman and Zhou 2007). ${ }^{4}$ Our study distinguishes itself in three aspects: First, we provide strong and positive evidence for a unitary board structure, which the literature has given relatively little attention. The unitary board structure is unique to the mutual fund industry and therefore there is a lack of applicable evidence from studies of industrial boards. ${ }^{5}$ Second, we provide a more complete analysis on fund fees. Whereas all other studies on fund fees focus exclusively on the quantitative aspect of fees, we supplement with an additional dimension: enforcement of breakpoints in the advisory fee structure, an action that takes place with a much higher frequency than actual fee changes. Finally, we examine the effect of a

\footnotetext{
${ }^{4}$ Other relevant studies include Ghosh and Sirmans (2003) and Hartzell, Sun, and Titman (2006) on real estate investment trusts, Varma (2003) on adviser effect, and Hermalin and Weisbach (2003) on corporate boards.

${ }^{5}$ We thank an anonymous reviewer for emphasizing this point.
} 
unitary board as well as other governance structure on fund shareholders' interests as well as director-shareholder and manager-shareholder conflicts of interest. Inference regarding a particular governance structure is based on consistent evidence of improving shareholder interest and mitigating agency conflicts. In earlier studies, a governance structure was captured by its effect on fund fees alone. Our study is among the first to explore other dimensions of governance effectiveness.

\section{Mutual Fund Governance}

\section{Institutional Background}

The current governance structure in the mutual fund industry is primarily shaped by the Investment Company Act of 1940, supplemented with SEC rules. Unlike that in corporations or even other financial service firms, such as banks, the governance structure for mutual funds features the least direct government regulation, heavy reliance on self-regulation, and emphasis on independent directors. Proper functioning of independent directors is implicitly viewed as the key to fund governance. This has been so because of the unique organizational structure of mutual funds. Different from the board serving corporations, a mutual fund board serves a different group of shareholders from that of the fund management or adviser. ${ }^{6}$ Because most fund advisers are compensated on the asset base, their ultimate task is to increase asset under management. However, the fund investors only care about realized net return after risk adjustment. This difference of objective creates a conflict of interest between fund managers and fund shareholders. ${ }^{7}$ Fund shareholders entrust the board of directors to safeguard their interests. Because affiliated directors would likely (and rationally) prioritize the interests of the management and the shareholders of the management company, there is a legitimate need to emphasize the monitoring role of independent directors, who act as sole fiduciaries to the shareholders of the fund.

In their function as fund shareholders' fiduciaries, fund directors, especially those who are independent, are expected to guard shareholders' wealth and advance shareholders' best interests. Important director fiduciary duties include both hiring the fund adviser and monitoring the fund managers:

\footnotetext{
${ }^{6}$ Two other noteworthy differences between corporate boards and mutual fund boards are, first, because mutual fund directors usually serve on multiple boards of funds in the same fund complex, they need to align the interests of shareholders across funds (e.g., in an in-family merger). Second, mutual fund directors do not directly get involved with the management of the funds. See Fama and Jensen (1985) for an illustration of the organizational differences between mutual funds and traditional corporations.

${ }^{7}$ See Chevalier and Ellison (1997) for empirical evidence and Mahoney (2004) for a detailed discussion on the manager-investor conflicts.
} 
- Review and approve the advisory contract. This is considered one of the most important aspects of fiduciary duties. An effective board would see meaningful declines in advisory fees as fund assets grow to reflect the benefits from economies of scale and pass the savings to shareholders. The use of a breakpoint in management fees is another effective technique to enforce the cost sharing between the management and the fund shareholders. In addition, an effective board would not allow fund expenses to stay above the average among its peer groups for a prolonged period.

- Monitor fund management and enforce legal compliance. The fund board is expected to guard investors' interest by proper risk management and pricing practices outlined in the investment objective or style. Although the fund board is discouraged from micromanaging the fund, it is expected to evaluate and monitor the performance of the management to reduce compliance violations to a minimum. Therefore, funds guarded by an effective board would be less likely to be involved in regulatory issues and would take timely and effective remedies in the unfortunate event of compliance violation.

More complete coverage of the fund board's fiduciary duties is provided by Jackson and Tate (2000). Tufano and Sevick (1997) also give an excellent overview of the legal and economic role of fund directors and other related issues regarding mutual fund governance.

Despite a relatively clean record in the past few decades, recent mutual fund scandals reveal troubling practices in the industry and indicate obvious abuses of investor trust as well as governance failures with some fund boards. ${ }^{8}$ The directors in the implicated funds either overlooked or knowingly allowed those apparent violations, and they were not very active in negotiating fees with fund advisers. ${ }^{9}$ To restore public confidence and to further tighten fund governance, on June 23 , 2004, the SEC mandated that funds have independent chairs and at least $75 \%$ independent directors. This fund governance reform has been controversial ever since it was proposed. The U.S. Chamber of Commerce even filed a lawsuit against the SEC for its abuse of regulatory authority. In an effort to resolve this controversy, the U.S. Congress required the SEC to provide a report on whether funds with independent chairs perform better, have lower expenses, or have better compliance

${ }^{8}$ Fund companies implicated in the market timing scandal managed a total of $\$ 1.6$ trillion of assets (Bogle 2005). Zitzewitz (2006) finds evidence of late trading in 39 of 66 fund families, which could have caused investor loss of $\$ 400$ million per year.

${ }^{9}$ Kuhnen (2004) shows that fewer than $10 \%$ of all U.S. funds undergo advisory contract change every year between 1993 and 2002. Seventy-seven percent of funds have no contract change between 1994 and 2001 in the sample examined by Warner and $\mathrm{Wu}(2006)$. 
records. On June 21, 2005, the U.S. Court of Appeals for the District of Columbia Circuit required the SEC reconsider the adoption of this rule. One week later, the SEC reaffirmed this rule adoption on June 29, 2005. The Chamber of Commerce subsequently challenged the rule again. In April 2006, the U.S. Court of Appeals for the District of Columbia Circuit concluded the SEC had violated the Administrative Procedure Act but delayed issuing its mandate vacating the mutual fund governance rules. The SEC announced reopening the rules for public comments in June and December 2006 and expected to reissue and finalize the rules by the end of 2007.

The key to the validity of the SEC rule is whether the current mutual fund board structure is an equilibrium outcome or out-of-equilibrium outcome. If it is an equilibrium outcome (i.e., it is endogeneously determined to balance the costs and benefits), the current board structure is optimal and hence any regulation cannot improve mutual fund governance. If it is an out-of-equilibrium outcome (i.e., market frictions prevent mutual funds from choosing a board better than their current boards), regulation may improve fund shareholders' welfare. ${ }^{10}$ However, it is hard to distinguish these two scenarios.

\section{Governance Mechanisms Through the Board of Directors}

In theory, mutual fund shareholders, like customers of any commodity, can always redeem their shares if they dislike the operations of the fund, therefore forcing fund advisers to act in the best interest of fund shareholders. The effectiveness of this external governance mechanism may be limited in reality: First, there are various financial obstacles that prevent investors from freely withdrawing funds and selecting the best funds. Redemption can be costly because of sales loads, redemption fees, and capital gains taxes, or unavailable because of possible restrictions of employer-sponsored fund programs. Second, the process of identifying the best funds and making the shift is costly and difficult. Sirri and Tufano (1998) argue that search costs can be substantial in the mutual fund market. Moreover, mutual fund investors can be misled by the brokers and media (Reuter and Zitzewitz 2006). Finally, studies show that, by and large, investors are not able to analyze market information accurately to make informed decisions and can be manipulated (see, e.g., Capon, Fitzsimmons, and Prince 1996; Del Guercio and Tkac 2002; Barber, Odean, and Zheng 2005; Elton, Gruber, and Busse 2004; Cooper, Gulen, and Rau 2005; Johnson 2006). Thus, it is practically insufficient to rely on market and investor monitoring alone. It is important to have well-designed internal governance mechanisms. In the following we discuss three internal governance mechanisms and their potential effectiveness.

\footnotetext{
${ }^{10}$ As discussed by Hermalin and Weisbach (2006), three necessary conditions for welfare-improving governance reforms are: (1) asymmetric information at contracting, (2) externalities on third party, and (3) more access to remedies or punishments.
} 
Board Independence. Interested directors of the board, who are employees or associates of the fund management company, will likely prioritize fund advisers' interests over fund shareholders' interests. This conflict of interest will undermine their ability to serve the fund shareholders. Therefore, more independent boards are more desirable from fund shareholders' perspective. However, identifying truly independent directors is difficult. Kuhnen (2007) emphasizes that business connections foster favoritism in the mutual fund industry. Fund directors prefer to hire advisers with past dealings and when they are more connected, advisers extract more rents and are monitored less intensely by the board. Because the new SEC rule does not emphasize past employment relations,${ }^{11}$ former employees of the management company may be counted as independent directors though they presumably have strong ties, psychologically or financially, to the management company. This contaminates the measure of board independence. After all, independence is an attitude rather than a statistic.

Director Incentives. Even truly independent directors may not deliver if they lack the motivation. When independent directors care more about their board seats and compensation than shareholders' interests, they are practically no different from affiliated directors in conducting fiduciary duties. One solution to enhancing independent directors' incentives and mitigating the shareholder-director conflict, as suggested by ICI and implicitly implemented by many mutual fund boards, is to require independent directors to hold a considerable stake in the funds they oversee. A preferred benchmark for a meaningful investment by independent directors is their annual compensation from the fund family. However, the effect of direct ownership on fund governance largely depends on whether the ownership is at the optimal level to induce positive incentives.

Unitary Board. A relatively less researched mutual fund governance mechanism is unitary board structure. As discussed in the introduction, a unitary board facilitates information sharing among funds and provides board directors more leverage in negotiating with the fund management companies and other service providers. Recent evidence shows that fund management companies play family strategies to maximize profits. A unitary board would counteract family strategy for fund investors. Pooled boards also make it convenient for the fund management companies to coordinate among different funds (e.g., cost sharing, fund distribution). Chen et al. (2004) demonstrate the importance of organizational diseconomies related to hierarchy costs. Another advantage of unitary boards includes better separation of governance from micromanagement. However, there are disadvantages to unitary boards, such as director's career concerns induced by high compensation and excessive workload.

\footnotetext{
${ }^{11}$ To qualify as an independent director, an individual must meet specific criteria under the Investment Company Act of 1940. An independent director cannot be an employee of the adviser or a member of the immediate family of an employee, be an employee or a 5\% shareholder of a registered broker-dealer, or have an affiliation with any recent legal counsel to the fund.
} 
In addition, we consider the effect of board size as previous studies (e.g., Tufano and Sevick 1997) suggest that larger boards are less effective. We do not have clear predictions about the effectiveness of board independence and director incentive before analyzing the data. However, we expect the benefits of unitary board to outweigh its costs because most fund administrative issues are repetitive in nature.

\section{Governance Effectiveness Measures}

Fund shareholders are the owners of the funds. Governance effectiveness is directly reflected by how fund shareholders interests are protected. ${ }^{12}$ Those interests include fund fees, performance, and flows. One way fund advisers can exploit fund shareholders is to charge excessively high fees. As discussed earlier, market competition alone may not be enough to eliminate this tunneling method. ${ }^{13}$ Our first measure of governance effectiveness is whether certain board structures are related to fair levels of fund fees, as fee setting is one of the primary responsibilities of mutual fund boards. All else equal, fund shareholders will prefer lower fund fees. Nevertheless, fund shareholders are willing to pay higher fees for better performing funds. Our second measure of governance effectiveness is fund performance. Governance will matter to performance if the board can identify skilled managers or if the board can restrain bad management practices. Consequently, those conditions will determine the power of performance as a measure of governance effectiveness. Finally, our third governance measure is fund flow. Shareholder interests may be affected by fund flows because funds with more volatile flows are harder to manage and are less tax efficient. However, fund flow may reveal fund shareholder preference toward certain governance structure. We hypothesize that better governed funds will attract more fund inflows.

Both boards of directors and fund advisers are agents of fund shareholders. Inevitably, we will observe two agency problems in mutual funds because of the director-shareholder and adviser-shareholder conflicts of interests. Arguably, effective governance will be indirectly reflected by how both layers of conflicts of interests are alleviated. Therefore, we use auxiliary measures of governance effectiveness to examine how directors and advisers fulfill their fiduciary duties. ${ }^{14}$

\footnotetext{
${ }^{12} \mathrm{We}$ thank the referee for suggesting the discussion in this section.

${ }^{13}$ Tkac (2004) discusses the customer role of fund shareholders and promote the power of market discipline. Nevertheless, fund advisers compete more by product differentiation than by price contest as financial products are seldom perceived to be identical. Khorana and Servaes (2007) show that the benefit to fund shareholders from competition is limited. Moreover, Keswani and Stolin (2006) show that competition could hurt fund performance. The rapid growth of the mutual fund industry (Gruber 1996) may also indicate that external competition with other financial services markets is not complete.

${ }^{14}$ Various ways of measuring effective governance are discussed in the literature. Del Guercio, Dann, and Partch (2003) study closed-end funds and consider a board effective if it can successfully and timely restructure the fund to reduce the magnitude of discount. Khorana, Tufano, and Wedge (2007) study fund mergers and argue that an effective board tolerates less underperformance. Ding and Wermers (2006) argue that an effective board is able to successfully replace underperforming managers.
} 
First, shareholders' interests may be better guarded by more diligent directors. We measure director diligence by the Morningstar stewardship rating and its components. Moreover, we study how directors help shareholders obtain the benefits of economies of scale and how active directors are when shareholders are not served well. Presumably, better governed funds will have higher Stewardship Ratings, more efficient breakpoints in fees, and more vigilant directors. Although the current mutual fund governance reform focuses on the board of directors, the root of all fund governance issues is the adviser-shareholder conflicts of interests. Recent fund scandals best reflect fund advisers' incentives to exploit fund shareholders by taking actions to increase fund assets, even though these actions can be costly to existing shareholders. These actions are probably motivated by the optionality embedded in the convex flow-performance relation (Sirri and Tufano 1998). Better governed funds should protect shareholders better against irregular trading practices and, consequently, should be less likely to be indicted in the recent scandals.

\section{Data and Empirical Method}

\section{Sample Description}

In February 2005, Morningstar released the first set of its mutual fund stewardship grades. Wellman and Zhou (2007) show that those stewardship grades have information content as capital is transferred from low-grade funds to high-grade funds. The availability of a stewardship grade depends on whether a fund responded to a lengthy and standardized survey sent out by Morningstar. The survey contained a combination of quantitative and qualitative questions, and Morningstar examined public filings and other sources to determine the grade.

These funds vary in size but they are mostly large funds. The stewardship grade intends to measure how well a fund conducts its fiduciary duties. The five components of Morningstar stewardship grades are: Regulatory Issues, Board Quality, Managerial Incentives, Fee Setting, ${ }^{15}$ and Corporate Culture. These grades are based on fund information in calendar year 2003, except for Regulatory Issues, which is based on information in the past three years ending in 2003. The Appendix provides details on the construction of Morningstar's stewardship grades. The overall stewardship grade as well as its five components are given on a scale of 5 with 5 being the most desirable. We use three components (Regulatory Issues, Fee Setting, and Corporate Culture) in the multivariate analysis. The Board Quality component

\footnotetext{
${ }^{15}$ Morningstar used the term "fees"; we label it "fee setting" to distinguish it from mutual fund fee level.
} 
overlaps with our independent variables, such as board independence and director incentives, and thus is left out. Another component, Managerial Incentives, is not analyzed because it evaluates the incentives of fund managers and thus bears little relevance for our study of board structure.

For the 969 funds with stewardship grades, we obtain fund board data from the Statement of Additional Information (in SEC filings 485APOS and 485BPOS), supplemented by Morningstar's description. The board structure variables include: (1) board size; (2) percentage of independent directors; (3) whether the board has an independent chair; (4) use of a unitary board, where one board oversees all funds in the family; and (5) director incentives, defined as the percentage of independent directors whose investments in the fund family are greater than their total compensation from the fund family or $\$ 100,000$, whichever is smaller. (Independent directors are only required to disclose their holdings in the ranges of $\$ 0$, $\$ 0-\$ 25,000, \$ 25,000-\$ 50,000, \$ 50,000-\$ 100,000$, and $\$ 100,000$ and above. We could not obtain exact ownership data.)

We merge the fund board data with the CRSP Survivorship-Free Mutual Fund database to obtain fund-specific information. The data items collected from 2003 include fund age, investment objective, fund size (total net assets), expense ratio, 12b-1 fee, total load, annual turnover ratio, and monthly returns. Management fees were collected from the Morningstar Web site (http://www.morningstar.com/fii/ fundindustryinvestigation.html). For funds with multiple classes, we retain the class with the largest asset. We also calculate statistics at the family level. These include family age, total net assets, family focus, and family classes from 2003. Family classes is the number of different fund classes offered by the fund family and family focus is the Herfindahl index on different investment objectives offered by the family. These two family-level variables are intended to capture cross-sectional variation in distribution channel and managerial complexity, respectively. Unitary board is identified by examining the number of funds overseen by a board and the total number of funds in the fund family. We started with 969 funds with board information. Among those, 949 funds from 126 fund families have nonmissing fund-specific information and therefore are used throughout the tests. Sample funds are classified into five categories according to their investment objectives: equity, bonds, blended, global, and specialized.

We measure fund performance as the continuously compounded monthly return over the entire year $t$ :

$$
\text { return }_{t}=\prod_{m=1}^{12}\left(1+r_{t, m}\right)-1,
$$

where $r_{t, m}$ is the month $m$ return in year $t$. Return volatility is measured as the standard deviation of 12 monthly returns. Fund flow is measured as: 


$$
\text { flow }_{t}=\frac{T N A_{t}-T N A_{t-1} \times \text { return }_{t}}{T N A_{t-1}},
$$

where TNA is the total net assets of the fund.

Table 1 provides the summary statistics of the sample. Because Morningstar's stewardship grades are assigned to relatively large funds, the average size (total net assets) of a sample fund is $\$ 2,701$ million, compared to $\$ 840$ million for the entire industry. The total value of all the funds in our sample is $\$ 2.6$ trillion, which amounts to $35 \%$ of the $\$ 7.4$ trillion of the universe of funds as of the end of 2003. The average fund age is 17 years. The funds have on average 9.2 directors and 7.2 independent directors. The average percentage of independent directors is $78 \%$, and among the independent directors $83 \%$ invest more than their compensation, or $\$ 100,000$. The mean stewardship grade is 3.42 . Unitary boards are present, with 681 funds and 99 of the 126 fund families. Before the passage of the new SEC rule, 149 boards already installed an independent chair and at least $75 \%$ independent directors. In total, an independent chair was installed in 162 boards, and 576 boards were staffed with $75 \%$ or more independent directors. There are 43 bank funds in our sample.

\section{Univariate Analysis on Governance Mechanisms}

In this section we use a comparison approach to examine whether unitary boards, enhanced board independence, or director incentive can significantly differentiate the funds. The main comparison aspects include the fee structure and the stewardship grade of the board.

Unitary Board. A unitary board is the extreme case of board oversight concentration. We define oversight concentration of a board as the portion of the fund family overseen by the board; a unitary board oversees $100 \%$ of a fund family. A unitary board provides the best leverage for the board to negotiate with the management company and other service providers. We expect unitary boards be more effective in negotiating lower fees and in safeguarding the interests of fund investors. Oversight concentration is primarily determined by the management company because the management company makes the decision to designate a new board or use the same board for each fund in the fund family. As reported in Table 2, 681 of the 949 funds use a unitary board; these funds charge significantly lower fees and rank significantly higher on the stewardship components Fee Setting, Regulatory Issues, and Corporate Culture. Board Quality is lower for unitary board probably because Morningstar gives lower rating to boards overseeing more than 12 funds. Managerial Incentives are indistinguishable regardless of whether a fund uses unitary board. Average reduction in annual fees is significant for unitary boards: $11 \mathrm{bps}$ in expense ratio, $11 \mathrm{bps}$ in management fee, 4 bps in 12b-1 fee, and $31 \mathrm{bps}$ in total load. The improvement in the overall stewardship rating is from 3.19 to 3.52 in mean. Funds with unitary boards tend to be larger and younger and have a larger 


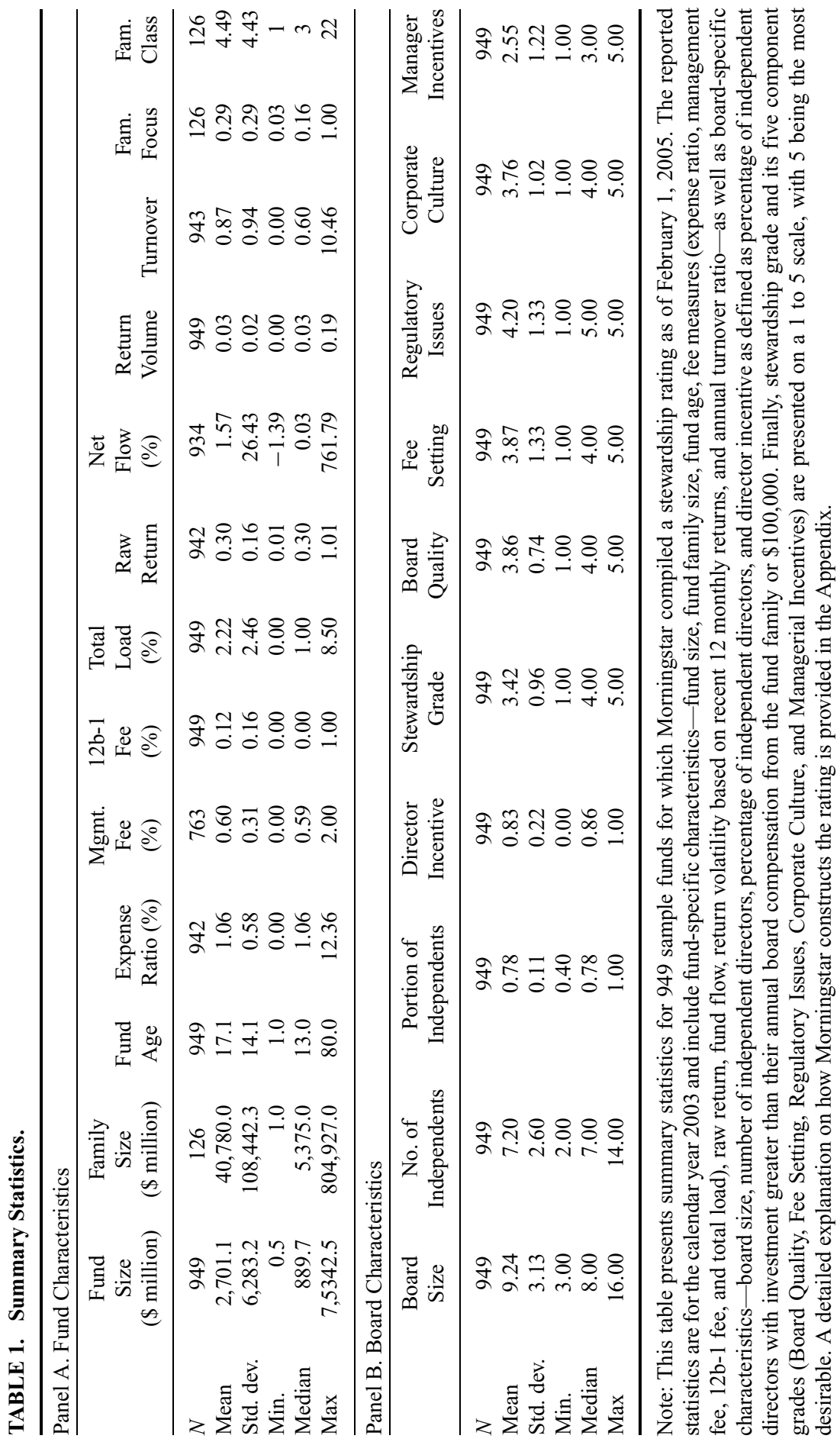




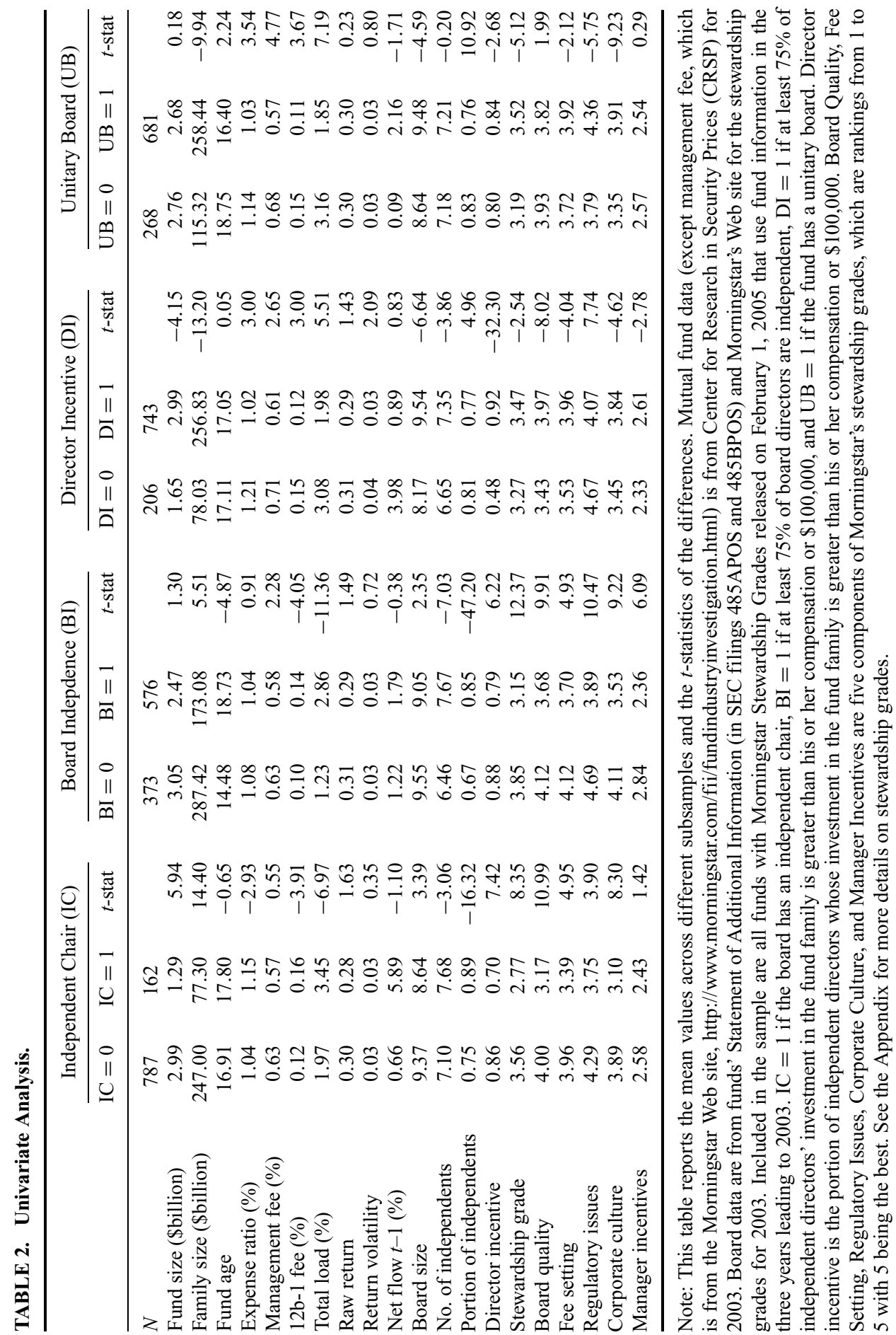


but less independent boards, where independent directors are more likely to hold more investment in the fund family. ${ }^{16}$

Board Independence. We find that enhanced board independence is not beneficial to shareholders. In Table 2, funds voluntarily complying with one or both independence requirements tend to charge higher fees, a 12b-1 fee or total load, than funds with a less independent board structure. Management fee is an exception. Although board chairman independence is not significantly associated with management fee, boards with more than $75 \%$ independent directors successfully reduce management fees. In addition to charging higher fees, complying funds also score significantly lower on the stewardship rating. Moreover, it seems that the more independent boards are further away from what we expect from an effective and better governed board. Specifically, funds with more independent boards are more likely to be involved in regulatory issues and/or fail to take timely and effective remedies in the event of breaches of fiduciary duty, more likely to charge fees above the average of their peer groups, and more likely to portray a negative image because of insufficient care for shareholders' interests. The mean overall stewardship rating is 2.77 for independently chaired boards and 3.56 for insider-chaired boards. Boards with more than $75 \%$ independent directors score 3.15 and those with fewer independent directors average 3.85. Furthermore, director incentive is lower for more independent boards.

Director Incentives. When a large percentage of independent directors own significant investments in the funds overseen, they would collectively be more motivated to discipline the management. We first examine whether a fund delivers better results when a supermajority of its independent directors hold significant investments (where the dummy variable $D I$ is set to 1 ). In Table 2, we find that when more than $75 \%$ of independent directors hold significant investments in the fund family relative to their compensation, funds tend to charge lower fees and score higher on stewardship ratings, except the component Regulatory Issues. Meschke (2007) also documents lower fees where independent directors hold a higher ownership conditional on lower compensation. Fund return volatility is notably higher when director incentive is lower. These findings are consistent with the conjecture that excessively compensated directors allow the advisers to charge high fees and restrict the managers less.

\section{Empirical Method}

To identify the effect of governance mechanisms, we need to isolate the effect from other sources that may be correlated with our governance effectiveness measures.

\footnotetext{
${ }^{16} \mathrm{We}$ also find (in unreported results) that when more $75 \%$ of independent directors hold significant investment, the number of funds they oversee in the same fund family is twice the mean and almost triple the median number of funds overseen by boards with less than $75 \%$ of independent directors investing significantly.
} 
Following the previous literature, we form a set of control variables at both the fund and fund family levels for our regression analysis, with a brief discussion on their predicted effect on fund fees.

- Family-level control variables: (1) Family focus: Family focus is defined as the Herfindall index of investment objectives in a fund family. More focused fund families are easier and less costly to monitor as their investment strategies are less diverse. (2) Family classes: The number of share classes proxies for the complexity of distribution channels and therefore relates to expense ratios. (3) Fund family size: Larger families tend to charge lower fees because of economies of scale and more bargaining power with other service providers.

- Fund-level control variables: (1) Board size: Large boards are less efficient and therefore tend to settle for higher fees. (2) Fund age: The effect is uncertain. Older funds may charge higher fees because they need to subsidize new and younger funds. They may also charge lower fees as most start-up costs have already been absorbed. (3) Fund size: Large funds tend to charge lower fees as a result of economies of scale. (4) Index fund: Index funds are passively managed, which likely results in lower cost of management. (5) Other fund-level control variables: past performance, fund flows, short-term return volatility, turnover ratio, and fund objectives.

We regress our direct measures of governance effectiveness for shareholder interests (fund fees, performance, and flows) and auxiliary measures of agency conflict mitigation (director stewardship and manager trading scandal involvement) on the governance mechanisms, in particular, unitary board, controlling for other nongovernance factors. Truly effective governance mechanisms would emerge from all analyses in a consistent manner.

\section{Governance Structure and Investor Welfare}

The ultimate goal of a good governance structure is to effectively promote fund investor's interests. Lowering fees and improving fund performance seem to top the list of investor interests. Though boards of directors may have direct influence on fee setting, they hardly have control over the fund's performance (aside from performance evaluation). The link between governance structure and fund performance is indirect. A well-governed board may exercise better monitoring of the management. Consequently, the manager may work more diligently or reduce value-diminishing misbehaviors. Both have the potential to enhance performance. Additionally, we study fund flows to assess whether investors have particular preferences over certain governance structures. 
Fee Analysis

Fee setting is arguably the most transparent reflection of the conflict of interests between the fund adviser and fund investors. Prior studies show that funds with higher expense ratios have lower returns (Blake, Elton, and Gruber 1993; Elton et al. 1993; Carhart 1997; Malhotra and MacLeod 1997; Wermers 2000). The board of directors is entrusted to negotiate a reasonable fee schedule with the management company. The expense ratio is a required disclosure for all funds. It includes management fee, $12 \mathrm{~b}-1$ fees, and other administrative expenses. Among these, 12b-1 fees and other administrative expenses are normally paid to other service providers to cover distribution costs and overhead, and the management fee is the primary compensation to the management company (Mahoney 2004; ICI 2004). This breakdown, however, does not imply that the fight over fees is relevant for the management fee alone because, in reality, the management company often functions as various service providers through its subsidiaries. (Dukes, English, and Davis 2006 show that $12 \mathrm{~b}-1$ fees can be more than deadweight cost.) Besides annual expenses, another relevant cost to fund investors is transaction-based load fees. We construct a measure of total fees that combines annual expenses with the load fees amortized over a certain holding horizon. According to ICI, the average holding period for a mutual fund is seven years. Therefore, following Sirri and Tufano (1998), we calculate the total fees as the sum of expense ratio and one-seventh of the total load fees:

\section{Total Fees = Annual Expense Ratio + Total Load Fees $/ 7$.}

The regression model used for fee analysis takes the general form:

$$
\text { Fees }_{i, t}=\alpha+\alpha \times U B+\alpha \times B I+\alpha \times D I+\sum_{k} \beta^{k} \times \text { ControlVariables }_{i, t}^{k}+\varepsilon_{i, t} \text {, }
$$

where $t=$ year 2003, $U B$ is the unitary board dummy variable, $B I$ is board independence (both independent chair dummy and a percentage of independent directors), and $D I$ is director incentive measure. Control variables are outlined in the methodology section.

Four relevant measures of fees are used in Table 3: expense ratio, 12b-1 fee, management fee, and total fees. Having a unitary board successfully reduces fees at the $1 \%$ significance level across all four fee measures. All else equal, funds with unitary boards have expense ratio 10 bps lower, 12b-1 fee 5 bps lower, and management fee 13 bps lower than funds governed by nonunitary boards. On average, unitary boards save investors 23 bps per year. In sharp contrast, funds with independent chairmen are no different from funds chaired by insiders in terms of all four fee measures. This is probably not surprising because the final determination of the advisory contract, including fee setting, is subject to approval by independent 
TABLE 3. Mutual Fund Fees and Governance Mechanisms.

\begin{tabular}{|c|c|c|c|c|c|c|c|c|}
\hline & \multicolumn{2}{|c|}{ Expense Ratio } & \multicolumn{2}{|c|}{$12 b-1$ Fee } & \multicolumn{2}{|c|}{ Management Fee } & \multicolumn{2}{|c|}{ Total Fee } \\
\hline & Coefficient & $t$-stat & Coefficient & $t$-stat & Coefficient & $t$-stat & Coefficient & $t$-stat \\
\hline Unitary board dummy & -0.10 & -3.10 & -0.05 & -3.19 & -0.13 & -6.01 & -0.23 & -4.78 \\
\hline Board size & 0.02 & 4.83 & 0.02 & 7.84 & 0.01 & 1.78 & 0.05 & 6.16 \\
\hline Independent chair dummy & 0.05 & 1.13 & 0.01 & 0.57 & -0.02 & -0.81 & 0.08 & 1.24 \\
\hline Board $75 \%$ independence & 0.03 & 1.07 & 0.06 & 4.40 & -0.03 & -1.72 & 0.19 & 4.49 \\
\hline Director incentive & -0.17 & -1.15 & -0.10 & -3.03 & 0.04 & 0.92 & -0.39 & -2.41 \\
\hline $\log ($ fund size $) t-1$ & -0.08 & -3.39 & 0.00 & 0.69 & -0.01 & -1.51 & -0.10 & -4.12 \\
\hline $\log ($ age $)$ & 0.03 & 0.40 & -0.03 & -2.23 & -0.05 & -3.36 & 0.10 & 1.50 \\
\hline Raw return $t-1$ & -0.07 & -0.16 & -0.18 & -2.79 & -0.03 & -0.33 & -0.27 & -0.58 \\
\hline Net flow $t-1$ & 0.00 & 0.14 & 0.00 & -0.67 & 0.00 & 0.66 & 0.00 & 0.11 \\
\hline Return volatility $t-1$ & 2.78 & 2.06 & 0.06 & 0.57 & 0.74 & 4.69 & 2.87 & 2.19 \\
\hline Turnover ratio $t-1$ & 0.01 & 1.26 & 0.00 & -0.45 & 0.02 & 1.85 & 0.01 & 0.54 \\
\hline Index fund dummy & -0.54 & -7.81 & -0.12 & -7.38 & -0.28 & -7.82 & -0.74 & -9.24 \\
\hline Bond fund dummy & -0.03 & -0.28 & -0.02 & -0.95 & -0.05 & -1.71 & -0.04 & -0.41 \\
\hline Blended fund dummy & -0.10 & -1.72 & -0.01 & -0.41 & -0.04 & -1.34 & -0.07 & -0.78 \\
\hline Equity fund dummy & -0.08 & -1.51 & -0.02 & -0.90 & 0.03 & 1.01 & -0.07 & -1.01 \\
\hline Global fund dummy & 0.16 & 3.15 & -0.03 & -1.15 & 0.15 & 3.94 & 0.25 & 3.52 \\
\hline $\log ($ family size $) t-1$ & -0.09 & -6.74 & -0.01 & -2.52 & -0.04 & -6.13 & -0.09 & -4.97 \\
\hline Family focus & 0.15 & 0.80 & -0.09 & -1.45 & 0.34 & 5.40 & 0.00 & 0.01 \\
\hline Family classes & 0.01 & 2.28 & 0.00 & -2.09 & 0.00 & 1.34 & 0.01 & 1.31 \\
\hline Intercept & 1.87 & 12.38 & 0.26 & 4.01 & 1.05 & 11.62 & 2.03 & 9.56 \\
\hline$N$ & 921 & & 921 & & 714 & & 921 & \\
\hline Adjusted $R^{2}$ & 0.469 & & 0.133 & & 0.455 & & 0.414 & \\
\hline
\end{tabular}

Note: This table illustrates the effects of fund governance mechanisms on mutual fund fees. Dependent variables are expense ratio, 12b-1 fee, management fee, and total fee (expense ratio plus one-seventh of total load). All fund data are for 2003. The default fund type is specialized funds. Family focus is the Herfindahl index for fund investment objectives. Family classes represent the number of fund classes offered by the fund family. Director incentive is defined as the portion of independent directors whose investment in the fund family is greater than his or her compensation or $\$ 100,000$. All $t$-values are robust with respect to heteroskedasticity.

directors only. Funds with more than $75 \%$ independent directors on the board have significantly higher 12b-1 fees (by 6 bps) and higher total fees (by 19 bps) at the $1 \%$ significance level, but lower management fee (by $3 \mathrm{bps}$ ) at $10 \%$ significance level. Higher director incentives significantly reduce $12 \mathrm{~b}-1$ fee and total fees, but have insignificant effect on expense ratio and management fee.

It is worth mentioning that our results on the control variables do not indicate any unreasonable fee levels (e.g., larger funds and fund families have lower fees, reflecting economies of scale). We confirm the findings of Lesseig, Long, and Smythe (2002) that fund families with more share classes have lower administrative fees but higher management fees. Consistent with previous studies (Tufano and Sevick 1997; Del Guercio, Dann, and Partch 2003), we find that funds with larger boards charge higher fees. If regulators are concerned over the fees charged to shareholders, our findings on the relation between fees and governance mechanisms suggest that recommending a unitary board with a smaller size and higher director incentive may be more fruitful than requiring higher board independence. 
TABLE 4. Mutual Fund Performance and Governance Mechanisms.

\begin{tabular}{|c|c|c|c|c|}
\hline & \multicolumn{2}{|c|}{ Raw Return } & \multicolumn{2}{|c|}{ Objective Adjusted } \\
\hline & Coefficient & $t$-stat & Coefficient & $t$-stat \\
\hline Unitary board dummy & 0.09 & 0.13 & 0.46 & 0.64 \\
\hline Board size & 0.00 & 0.03 & -0.29 & -2.49 \\
\hline Independent chair dummy & -0.63 & -0.70 & 0.16 & 0.20 \\
\hline Board $75 \%$ independence & -0.38 & -0.56 & -1.43 & -2.25 \\
\hline Director incentive & 0.82 & 0.35 & 0.53 & 0.28 \\
\hline $\log ($ fund size $) t-1$ & -0.85 & -2.36 & -0.83 & -2.77 \\
\hline $\log ($ age $)$ & -2.21 & -2.45 & -0.68 & -1.00 \\
\hline Raw return $t-1$ & -2.07 & -0.34 & 10.29 & 1.52 \\
\hline Net flow $t-1$ & -0.01 & -0.06 & -0.06 & -0.36 \\
\hline Return volatility $t-1$ & 110.08 & 6.81 & 47.06 & 3.66 \\
\hline Turnover ratio $t-1$ & 0.19 & 0.64 & 0.89 & 2.97 \\
\hline Index fund dummy & 0.67 & 0.43 & 0.41 & 0.36 \\
\hline Bond fund dummy & -2.10 & -1.38 & & \\
\hline Blended fund dummy & 2.95 & 2.53 & & \\
\hline Equity fund dummy & 4.93 & 4.03 & & \\
\hline Global fund dummy & 12.79 & 10.05 & & \\
\hline $\log ($ family size $) t-1$ & 0.15 & 0.47 & 0.32 & 1.08 \\
\hline Family focus & 4.00 & 1.23 & -1.36 & -0.46 \\
\hline Family classes & -0.14 & -1.66 & -0.06 & -0.86 \\
\hline Intercept & 16.22 & 4.40 & 2.57 & 0.80 \\
\hline$N$ & 921 & & 921 & \\
\hline Adjusted $R^{2}$ & 0.656 & & 0.195 & \\
\hline
\end{tabular}

Note: This table illustrates the effects of fund governance mechanisms on mutual fund performance. Dependent variables are raw annual returns and objective-adjusted annual returns. All fund data are for 2003. The default fund type is specialized funds. Family focus is the Herfindahl index for fund investment objectives. Family classes represent the number of fund classes offered by the fund family. Director incentive is defined as the portion of independent directors whose investment in the fund family is greater than his or her compensation or $\$ 100,000$. All $t-1$ values are robust with respect to heteroskedasticity.

\section{Performance Analysis}

The principal interest for shareholders is fund returns after fees and risk adjustments. Because the board is discouraged from micromanaging the fund, it should not directly affect fund performance except by monitoring performance and establishing performance guidelines. In addition, in an efficient market where financing and investment are perfectly separable, how a board is structured is irrelevant to the performance of the fund. Without transaction costs, fund investors are able to punish funds with bad governance through redemption. In practice, there are various factors that hinder the power of market force, such as sales load, redemption fees, and capital gains taxes. There is arguably less shareholder-manager conflict of interests regarding performance, which may further obscure the governance-performance relation. Ultimately, whether fund governance matters to performance is an empirical issue.

In Table 4, performance is measured in both raw return and objectiveadjusted return. In the measure of raw return, performance is directly related to 
fund size, fund age, return volatility, and fund objective. Specifically, significant underperformance is observed in larger and older funds and less risky funds. None of the governance structures is significantly related to raw return. The insignificance of board independence on fund performance is also documented by Meschke (2007) and Cremers et al. (Forthcoming). Wellman and Zhou (2007) show that funds with better performance receive higher a Morningstar stewardship grade, which is positively related to board independence. When performance is adjusted by fund objective, fund with larger boards and boards with more than $75 \%$ independent directors actually underperform. In 2003, funds overseen by boards with more than $75 \%$ independent directors underperformed their peers by $1.43 \%$. These findings further support our previous proposition that limiting board size may be more useful than board independence.

\section{Fund Flows Analysis: Do Investors Have a Preference for Good Governance?}

We also study fund flows to check whether investors appreciate a particular governance structure, such as a unitary board, more board independence, or more director incentive. As documented in the prior literature (Zheng 1999), fund investors have superior selection ability, and funds that attract the highest fund inflows outperform those with the lowest fund growth. Thus, if investors have preference for certain board structure, significant fund growth will result. In Table 5, we regress fund flows on the governance structure variables and control variables. We find that fund investors have a strong preference for unitary boards, and unitary boards contribute to $18 \%$ of fund flows. We also find that fund investors do not particularly care for board independence. Neither an independent chair nor a supermajority of independent directors is rewarded by more fund flows. All else equal, funds with independent chairmen and more than $75 \%$ independent directors experience a $9 \%$ ( $t$-value of 1.89) outflow in 2003. Funds with 100\% independent directors lost 14\% of their assets to other funds. Our flow results further advocate unitary boards and against board independence.

\section{Governance Structure and Agency Problems}

In the previous section, we examine how governance mechanisms are directly related to shareholders' interests in fees, performance, and flows. Shareholders' interests are ultimately imperiled by conflicts with directors' and advisers' interests (see Ferris and Yan 2007a for a discussion of namesake funds). To shed further light on the governance effectiveness and assure the robustness of our findings in the previous section, we investigate how governance mechanisms alleviate those conflicts of interest through director stewardship performance and managers' involvement in trading scandals. 
TABLE 5. Fund Flow Analysis: Do Investors Prefer Certain Governance Structure?

\begin{tabular}{|c|c|c|c|c|c|c|}
\hline & \multicolumn{2}{|c|}{ Model (1) } & \multicolumn{2}{|c|}{ Model (2) } & \multicolumn{2}{|c|}{ Model (3) } \\
\hline & Coefficient & $t$-stat & Coefficient & $t$-stat & Coefficient & $t$-stat \\
\hline Unitary board dummy & 0.18 & 3.83 & 0.17 & 3.97 & 0.18 & 4.21 \\
\hline Board size & -0.01 & -0.93 & -0.01 & -0.95 & -0.01 & -1.21 \\
\hline Independent chair dummy (IC) & -0.01 & -0.12 & & & & \\
\hline Board $75 \%$ independence dummy (BI) & 0.01 & 0.18 & & & & \\
\hline $\mathrm{IC} \times \mathrm{BI}$ & & & -0.09 & -1.89 & & \\
\hline Board $100 \%$ independence dummy & & & & & -0.14 & -2.12 \\
\hline Director incentive & 0.13 & 0.92 & 0.09 & 0.71 & 0.10 & 0.76 \\
\hline $\log ($ fund size $) t-1$ & -0.07 & -3.13 & -0.08 & -3.17 & -0.07 & -3.14 \\
\hline Log(age) & -0.15 & -3.30 & -0.15 & -3.23 & -0.15 & -3.28 \\
\hline Raw return $t-1$ & 0.97 & 3.94 & 0.96 & 3.88 & 0.96 & 3.89 \\
\hline Net flow $t-1$ & 0.02 & 1.31 & 0.02 & 1.32 & 0.02 & 1.32 \\
\hline Return volatility $t-1$ & 0.26 & 0.57 & 0.25 & 0.55 & 0.24 & 0.53 \\
\hline Turnover ratio $t-1$ & -0.03 & -1.84 & -0.03 & -1.80 & -0.03 & -1.89 \\
\hline Index fund dummy & 0.10 & 1.20 & 0.10 & 1.13 & 0.11 & 1.22 \\
\hline Bond fund dummy & 0.03 & 0.27 & 0.03 & 0.34 & 0.03 & 0.34 \\
\hline Blended fund dummy & 0.19 & 2.81 & 0.19 & 2.93 & 0.19 & 2.89 \\
\hline Equity fund dummy & 0.18 & 2.62 & 0.18 & 2.60 & 0.18 & 2.60 \\
\hline Global fund dummy & 0.28 & 3.05 & 0.28 & 3.05 & 0.28 & 3.06 \\
\hline $\log ($ family size $) t-1$ & -0.04 & -1.28 & -0.04 & -1.22 & -0.04 & -1.31 \\
\hline Family focus & 0.10 & 0.47 & 0.08 & 0.38 & 0.08 & 0.37 \\
\hline Family classes & 0.00 & 0.39 & 0.00 & 0.34 & 0.00 & 0.68 \\
\hline Intercept & 1.24 & 3.74 & 1.29 & 3.72 & 1.31 & 3.67 \\
\hline$N$ & 910 & 910 & 910 & & & \\
\hline Adjusted $R^{2}$ & 0.169 & & 0.172 & & 0.171 & \\
\hline
\end{tabular}

Note: This table illustrates the effects of fund governance mechanisms on fund net flows. Dependent variable is fund annual return-adjusted net flow:

$$
\text { flow }_{t}=\frac{T N A_{t}-T N A_{t-1} \times \text { return }_{t}}{T N A_{t-1}} .
$$

All fund data are for 2003. The default fund type is specialized funds. Family focus is the Herfindahl index for fund investment objectives. Family classes represent the number of fund classes offered by the fund family. Director incentive is defined as the portion of independent directors whose investment in the fund family is greater than his or her compensation or $\$ 100,000$. All $t$-values are robust with respect to heteroskedasticity.

\section{Governance Structure and Director Stewardship}

We examine whether a unitary board helps directors better fulfill fiduciary duties. We use the stewardship grade data from Morningstar and create two new measures extracted from the same data. In the first measure, we examine whether a particular board structure is linked to more efficiency in setting breakpoints in the fee schedule. As a fund grows, economies of scale result in lower cost of management. Ideally, the cost savings should be passed to investors. However, in practice, changes in fees are infrequent and investors count on built-in breakpoints in the fee schedule to benefit from economies of scale. In the second measure, we examine the overall 
TABLE 6. Morningstar's Stewardship Rating and Governance Structure.

\begin{tabular}{|c|c|c|c|c|c|c|}
\hline & \multicolumn{2}{|c|}{ Fee Setting } & \multicolumn{2}{|c|}{ Regulatory Issues } & \multicolumn{2}{|c|}{ Corporate Culture } \\
\hline & Coefficient & $z$ & Coefficient & $z$ & Coefficient & $z$ \\
\hline Unitary board dummy & 0.26 & 1.53 & 1.38 & 5.87 & 1.08 & 5.26 \\
\hline Board size & -0.09 & -3.24 & -0.14 & -3.57 & -0.12 & -3.79 \\
\hline Independent chair dummy & -0.49 & -2.83 & -0.86 & -3.61 & -1.05 & -4.29 \\
\hline Board $75 \%$ independence dummy & -0.66 & -4.07 & -1.63 & -7.79 & -0.99 & -6.70 \\
\hline Director incentive & 0.11 & 0.36 & -4.11 & -5.73 & -0.39 & -1.03 \\
\hline $\log ($ fund size $) t-1$ & 0.06 & 1.07 & -0.07 & -1.03 & -0.02 & -0.29 \\
\hline Log(age) & 0.11 & 0.98 & 0.04 & 0.30 & -0.21 & -1.69 \\
\hline Raw return $t-1$ & 2.21 & 3.14 & 2.44 & 1.93 & 2.79 & 3.44 \\
\hline Net flow $t-1$ & 0.01 & 0.32 & 0.45 & 1.39 & 0.00 & -0.23 \\
\hline Return volatility $t-1$ & 1.22 & 1.17 & 1.44 & 0.58 & 1.44 & 0.96 \\
\hline Turnover ratio $t-1$ & -0.14 & -2.07 & -0.07 & -0.90 & -0.14 & -1.73 \\
\hline Index fund dummy & 1.09 & 2.49 & 0.31 & 0.46 & 1.12 & 3.80 \\
\hline Bond fund dummy & -0.14 & -0.49 & -0.38 & -1.15 & -0.28 & -1.17 \\
\hline Blended fund dummy & 0.23 & 0.74 & 0.52 & 1.33 & 0.15 & 0.54 \\
\hline Equity fund dummy & -0.11 & -0.50 & 0.18 & 0.67 & 0.22 & 1.08 \\
\hline Global fund dummy & 0.25 & 0.94 & 0.24 & 0.83 & 0.30 & 1.35 \\
\hline $\log ($ family size $) t-1$ & 0.56 & 8.79 & 0.53 & 7.09 & 0.60 & 9.23 \\
\hline Family focus & 1.19 & 2.04 & 2.17 & 2.46 & 4.24 & 5.46 \\
\hline Family classes & -0.07 & -4.32 & -0.09 & -4.62 & -0.16 & -9.52 \\
\hline$N$ & 921 & & 921 & & 921 & \\
\hline Pseudo $R^{2}$ & 0.098 & & 0.201 & & 0.210 & \\
\hline
\end{tabular}

Note: This table shows ordered logistic regression results for mutual fund board performance as measured by three components of Morningstar's stewardship grades: Fee Setting, Regulatory Issues, and Corporate Culture. Each of those components takes a value between 1 and 5 , with 5 being the best. See the Appendix for more details on how Morningstar constructed those ratings. This information is taken from Morningstar's stewardship grades. All fund data are for 2003. Family focus is the Herfindahl index for fund investment objectives. Family classes represent the number of fund classes offered by the fund family. Director incentive is defined as the portion of independent directors whose investment in the fund family is greater than his or her compensation or $\$ 100,000$. All $z$-values are robust with respect to heteroskedasticity.

activeness of a board and whether such activeness is associated with a particular governance structure.

Stewardship Rating. Using the newly released stewardship rating from Morningstar, we examine how well a board conducts its fiduciary duties. The stewardship rating is based on five components as explained in the Appendix, and we focus on three components of the stewardship rating: Regulatory Issues, Fee Setting, and Corporate Culture. An effective governance structure is expected to motivate the directors to excel in these three aspects. Specifically, motivated directors are expected to reduce the likelihood of compliance violations, negotiate a reasonable fee schedule on behalf of fund investors, enforce breakpoints to allow investors to benefit from economies of scale, and take their fiduciary function seriously in perceivable ways.

An ordinal logistic model is used and regression results are presented in Table 6 . Use of a unitary board consistently boosts a higher rating in all three 
components and such effect is significant on the rating on Regulatory Issues and Corporate Culture. (One possible reason for the lower significance of Fee Setting is that it is not directly based on the level of fees; instead, it captures whether a fund charges higher fees than that of its peer group defined as its Morningstar category.) In contrast, enhanced board independence seems to contribute to lower stewardship rating. That includes allowing the expense ratio to continuously stay above the category average, frequent implications in regulatory issues, and presenting a negative public image because of insufficient care of shareholder interests. Director incentive is only significant in its effect on Regulatory Issues. Consistent with our univariate analysis, a higher level of director incentive is found to be detrimental to a fund's experience with regulatory issues. Further exploration of optimal compensation for independent directors calls for theoretical development and is beyond the scope of this article. Finally, we find that larger boards receive lower stewardship grades. Our results on director stewardship are consistent with our previous finding for a unitary board with smaller size.

Economies of Scale and Breakpoint Setting. A major source of conflict of interest between the adviser and fund investors is how the benefits from economies of scale are shared. Although negotiating a lower fee can directly reduce shareholder cost, it does not occur frequently in practice. The routine advisory fee negotiation centers on setting breakpoints in the fee structure, with management preferring a higher breakpoint or no breakpoints at all. Without breakpoints in the advisory fee schedule, the adviser would pocket all the savings and leave fund investors bearing the high cost. In fact, the concern is validated by Kuhnen (2004), who documents that only $10 \%$ of the advisory contracts are revised each year, an infrequent event considering the exponential asset growth. We expect that an effective board is more likely to enforce effective breakpoints in the fee schedule.

Use of breakpoints in the fee schedule is derived from the component Fee Setting from Morningstar's stewardship grades. The Fee Setting rating is based on two factors: whether the fund's expense ratio is below or above the average ratio among its peer group and whether effective breakpoints are installed in the fee schedule. We first estimate whether a fund's expense ratio is below or above the group ratio, where the group is defined by Morningstar's investment objective. Funds that charge below-average fees receive a score of 1 and those that charge above-average fees receive a score of 0 . Combining this with the numerical score for the Fee Setting component, we can back out information on the use of breakpoints. Specifically, funds are categorized into three groups based on the use of breakpoints: no breakpoints, having breakpoints but set less effectively, and having effective breakpoints. The dependent variable in Table 7 takes the value of 0,1 , and 2 (most efficient breakpoints).

In Table 7, we present the results from an ordinal logistic model. The dependent variable is the degree to which a board enforces breakpoints effectively. Unitary boards are shown to be related to a higher level of efficiency in breakpoints 
TABLE 7. Breakpoint Setting in Fees and Board Structure.

\begin{tabular}{|c|c|c|c|c|c|c|}
\hline & \multicolumn{2}{|c|}{ Model (1) } & \multicolumn{2}{|c|}{ Model (2) } & \multicolumn{2}{|c|}{ Model (3) } \\
\hline & Coefficient & $Z$ & Coefficient & $Z$ & Coefficient & $Z$ \\
\hline Unitary board dummy & 0.27 & 1.56 & 0.51 & 3.25 & 0.60 & 4.03 \\
\hline Board size & -0.09 & -3.33 & -0.11 & -3.76 & -0.11 & -3.90 \\
\hline Independent chair dummy (IC) & -0.38 & -2.12 & & & & \\
\hline Board $75 \%$ independence dummy $(\mathrm{BI})$ & -0.70 & -4.07 & & & & \\
\hline $\mathrm{IC} \times \mathrm{BI}$ & & & -0.66 & -3.49 & & \\
\hline Board $100 \%$ independence dummy & & & & & -0.61 & -1.71 \\
\hline Director incentive & 0.12 & 0.38 & 0.30 & 0.94 & 0.43 & 1.30 \\
\hline $\log ($ fund size $) t-1$ & -0.04 & -0.74 & -0.03 & -0.58 & -0.02 & -0.42 \\
\hline $\log ($ age $)$ & 0.08 & 0.72 & 0.02 & 0.18 & 0.00 & -0.01 \\
\hline Raw return $t-1$ & 1.70 & 2.67 & 1.66 & 2.46 & 1.65 & 2.56 \\
\hline Net flow $t-1$ & 0.00 & -0.13 & -0.01 & -0.26 & -0.01 & -0.25 \\
\hline Return volatility $t-1$ & 0.35 & 0.34 & 0.58 & 0.55 & 0.51 & 0.50 \\
\hline Turnover ratio $t-1$ & -0.20 & -2.65 & -0.19 & -2.52 & -0.20 & -2.67 \\
\hline Index fund dummy & 0.88 & 2.09 & 0.87 & 2.16 & 0.94 & 2.37 \\
\hline Bond fund dummy & -0.01 & -0.02 & -0.02 & -0.07 & -0.03 & -0.11 \\
\hline Blended fund dummy & 0.20 & 0.61 & 0.15 & 0.45 & 0.12 & 0.37 \\
\hline Equity fund dummy & 0.03 & 0.14 & -0.06 & -0.29 & -0.07 & -0.30 \\
\hline Global fund dummy & 0.26 & 0.99 & 0.15 & 0.56 & 0.16 & 0.60 \\
\hline $\log ($ family size $) t-1$ & 0.54 & 8.42 & 0.53 & 8.31 & 0.51 & 7.98 \\
\hline Family focus & 1.16 & 2.15 & 1.24 & 2.23 & 1.29 & 2.32 \\
\hline Family classes & -0.05 & -2.96 & -0.04 & -2.44 & -0.03 & -1.67 \\
\hline$N$ & 921 & & 921 & & 921 & \\
\hline Pseudo $R^{2}$ & 0.105 & & 0.097 & & 0.092 & \\
\hline
\end{tabular}

Note: This table shows ordered logistic regression results for mutual fund breakpoint setting in fees. The dependent variable takes the value of 0 if the fund seldom set breakpoints in its expense ratio, 1 if it sets breakpoints but not sufficiently, and 2 for maximally effective breakpoints. This information is taken from Morningstar's stewardship grades. See the Appendix for more details on stewardship grades. All fund data are for 2003. The default fund type is specialized funds. Family focus is the Herfindahl index for fund investment objectives. Family classes represent the number of fund classes offered by the fund family. Director incentive is defined as the portion of independent directors whose investment in the fund family is greater than his or her compensation or $\$ 100,000$. All $z$-values are robust with respect to heteroskedasticity.

setting, with $t$-values of $1.56,3.25$, and 4.03 across the three models, respectively. More independent boards have a significantly lower likelihood of setting effective breakpoints, whereas director incentive does not show any significant effect. In addition, large fund families do better in setting breakpoints, whereas the size of individual funds does not matter. This is because the benefits from economics of scale occur primarily at the fund family level instead of the fund level. Larger boards, again, do worse in setting breakpoints.

Board Activeness. A higher stewardship rating implies that a board is active in taking actions where investors' interests are compromised. This could apply to routine tasks as well as major decisions. The level of activeness demonstrated in a board can be difficult to capture given the complexity of the fiduciary function and it may involve subjective evaluation. Our novel approach is to create a measure 
TABLE 8. Board Activeness and Board Structure.

\begin{tabular}{|c|c|c|c|c|c|c|}
\hline & \multicolumn{2}{|c|}{ Model (1) } & \multicolumn{2}{|c|}{ Model (2) } & \multicolumn{2}{|c|}{ Model (3) } \\
\hline & Coefficient & $Z$ & Coefficient & $Z$ & Coefficient & $Z$ \\
\hline Unitary board dummy & -0.48 & -1.57 & 0.80 & 2.94 & 1.03 & 4.82 \\
\hline Board size & -0.22 & -4.65 & -0.31 & -6.09 & -0.30 & -7.05 \\
\hline Independent chair dummy (IC) & -2.55 & -8.19 & & & & \\
\hline Board $75 \%$ independence dummy (BI) & -4.65 & -7.07 & & & & \\
\hline $\mathrm{IC} \times \mathrm{BI}$ & & & -3.63 & -9.17 & & \\
\hline Board $100 \%$ independence dummy & & & & & -4.16 & -5.83 \\
\hline Director incentive & -0.72 & -1.24 & 0.00 & 0.01 & 1.01 & 1.89 \\
\hline $\log ($ fund size $) t-1$ & 0.11 & 0.99 & 0.19 & 2.00 & 0.21 & 2.32 \\
\hline Log(age) & -0.39 & -1.88 & -0.65 & -3.47 & -0.76 & -3.71 \\
\hline Raw return $t-1$ & 3.06 & 1.83 & 3.50 & 2.20 & 2.41 & 1.75 \\
\hline Net flow $t-1$ & 0.20 & 0.72 & 0.15 & 0.57 & 0.18 & 0.84 \\
\hline Return volatility $t-1$ & 0.58 & 0.14 & 2.85 & 0.96 & 1.32 & 0.52 \\
\hline Turnover ratio $t-1$ & -0.17 & -2.09 & -0.08 & -0.75 & -0.09 & -0.89 \\
\hline Index fund dummy & 0.03 & 0.07 & 0.44 & 0.99 & 1.03 & 2.02 \\
\hline Bond fund dummy & -0.98 & -1.85 & -0.75 & -1.57 & -0.60 & -1.51 \\
\hline Blended fund dummy & 0.24 & 0.52 & -0.10 & -0.23 & -0.17 & -0.42 \\
\hline Equity fund dummy & 0.24 & 0.58 & -0.27 & -0.82 & -0.17 & -0.60 \\
\hline Global fund dummy & 0.74 & 1.53 & 0.20 & 0.49 & 0.30 & 0.87 \\
\hline $\log ($ family size $) t-1$ & 1.09 & 5.82 & 1.27 & 6.79 & 0.93 & 6.02 \\
\hline Family focus & 12.07 & 1.58 & 16.06 & 2.13 & 18.06 & 2.27 \\
\hline Family classes & -0.30 & -7.52 & -0.21 & -6.83 & -0.11 & -4.00 \\
\hline Intercept & -1.03 & -0.42 & -7.85 & -3.65 & -6.74 & -3.48 \\
\hline$N$ & 921 & & 921 & & 921 & \\
\hline Pseudo $R^{2}$ & 0.565 & & 0.447 & & 0.361 & \\
\hline
\end{tabular}

Note: This table shows logistic regression results for board activeness. The dependent variable is a dummy variable measuring whether the board takes action when the fund shareholders are clearly not served well. This information is extracted from Morningstar's Stewardship Grades. See the Appendix for more details on stewardship grades. All fund data are for 2003. The default fund type is specialized funds. Family focus is the Herfindahl index for fund investment objectives. Family classes represent the number of fund classes offered by the fund family. Director incentive is defined as the portion of independent directors whose investment in the fund family is greater than his or her compensation or $\$ 100,000$. All $z$-values are robust with respect to heteroskedasticity.

based on the Board Quality component from Morningstar's Stewardship Rating. Board Quality is evaluated based on four factors: (1) board activeness: whether the board has taken actions in cases where the fund clearly has not served the shareholders well; (2) independent director incentives; (3) oversight concentration: the number of funds overseen; and (4) board independence: whether the board meets the $75 \%$ independence. As we collect data for three of four factors (factors 2, 3, and 4) and combine them with the total score for Board Quality, we are able to derive the score on board activeness, a dummy variable that takes the value of 1 if a board is active and 0 otherwise.

Using a logistic analysis on this dummy variable, we examine which governance structure contributes to an active board. Table 8 shows that unitary boards 
seem to significantly improve board activeness in two of the three regressions. In contrast, more independent boards tend to be less active in taking actions to protect shareholder interests. For boards that install 100\% independent directors, the level of activeness is significantly lower still. Director incentive does not present consistent evidence on its effect on board activeness. Finally, it is interesting to note that larger boards seem to be less active. With no knowledge about what actions are taken and the effectiveness of any action, we should be cautious in interpreting these results. At the least, we show that unitary boards, compared to other governance structures, are more likely to promote timely actions from the board when shareholder interests are compromised.

\section{Governance Structure and Trading Scandals}

A critical role for a board is to guard the interests of fund investors from being exploited by fund managers. An effective governance structure is expected to curb value-diminishing activities by fund managers. In this section we examine an extreme of such managerial misbehavior: trading scandals. The triggering event to this round of fund governance regulation is the recent fund scandals, namely, market timing and late trading. We investigate whether a unitary board is significantly related to a fund's likelihood to commit scandals and whether other governance structures might serve as better deterrents to fund scandals. We obtain the scandal-indicted fund list from Morningstar's Fund Industry Investigation Update (http://www.morningstar.com/fii/fundindustryinvestigation.html) and Wall Street Journal Online's Mutual Funds Scandal Scorecard (http:/online.wsj.com/ documents/info-mfsc04.html). Among the 126 fund families in our sample, 18 were involved in market timing, 4 in both market timing and late trading, and 1 was alleged for mispricing.

We first estimate logistic regressions on a scandal indicator ( 1 for funds implicated with any kind of scandal). We then separate out funds with two accounts of accusations from those with one account and estimate ordinal logistic regressions. In the ordinal logistic regressions, the dependent variable takes the value of 0 for funds that have no trading scandals, 1 for one account, and 2 for two accounts. Family-level data are used in the regressions. Family age is the age of the oldest fund in the family and family size the cumulative total net assets of all funds in the family. Other independent variables are value weighted by the total net assets of individual funds in the family. Results are presented in Table 9. Funds with unitary boards are less likely to be implicated in scandals, significantly so in the ordinal logistic regression. Board independence and director incentive are not related to the likelihood of scandals. In fact, six of the scandalized fund families have both independent chairs and more than $75 \%$ independent directors.

What types of fund families are more likely to be involved in scandals? First, the size of the fund family is positively related to the scandal likelihood. It is 
TABLE 9. Fund Governance and Fund Scandals.

\begin{tabular}{|c|c|c|c|c|c|c|c|c|}
\hline & \multicolumn{2}{|c|}{ Model (1) } & \multicolumn{2}{|c|}{ Model (2) } & \multicolumn{2}{|c|}{ Model (3) } & \multicolumn{2}{|c|}{ Model (4) } \\
\hline & Coefficient & $z$ & Coefficient & $z$ & Coefficient & $z$ & Coefficient & $z$ \\
\hline Unitary board dummy & -0.95 & -1.64 & -0.96 & -1.65 & -1.16 & -1.99 & -1.17 & -2 \\
\hline Ind. chair dummy & 0.3 & 0.42 & 0.29 & 0.41 & 0.31 & 0.51 & 0.31 & 0.51 \\
\hline Percentage of ind. directors & 2.76 & 0.87 & 2.71 & 0.86 & 1.36 & 0.45 & 1.3 & 0.43 \\
\hline Board size & 0.04 & 0.29 & 0.06 & 0.41 & 0.1 & 0.78 & 0.12 & 0.88 \\
\hline Director incentive & 1.53 & 0.97 & 1.45 & 0.93 & 1.32 & 0.96 & 1.23 & 0.92 \\
\hline Log(fund family size) & 0.93 & 3.58 & 0.88 & 3.6 & 0.95 & 3.68 & 0.9 & 3.66 \\
\hline Fund family age & -0.03 & -2.12 & -0.03 & -1.98 & -0.04 & -2.5 & -0.03 & -2.39 \\
\hline Expense ratio & 0.92 & 2.69 & & & 0.95 & 2.76 & & \\
\hline Expense ratio $-12 b-1$ & & & 0.83 & 2.54 & & & 0.86 & 2.64 \\
\hline Const. & -13.41 & -3.66 & -12.83 & -3.59 & & & & \\
\hline$N$ & 126 & & 126 & & 126 & & 126 & \\
\hline Pseudo $R^{2}$ & 0.32 & & 0.31 & & 0.27 & & 0.27 & \\
\hline
\end{tabular}

Note: This table shows logistic regression results on the probability of fund scandals. Scandal data are from Morningstar Fund Industry Investigation Update and Wall Street Journal Online Mutual Funds Scandal Scorecard. All fund data are for 2003. Logistic analysis on the determinants of fund scandals. For the logit analyses, the dependent variable is a dummy variable where 1 is scandal fund families. For the ordered logit analyses, the dependent variable is 1 for market timing scandal families, 2 for market timing and late trading families, and 0 for no scandal families. Director incentive is defined as the portion of independent directors whose investment in the fund family is greater than his or her compensation or $\$ 100,000$. Fund level data are aggregated using TNA as the weight. All $z$-values are robust with respect to heteroskedasticity.

generally believed that fund families allow market timing and late trading in certain funds in exchange for more investments in other funds of the family. Ultimately, management's compensation is determined by the total size of the family. ${ }^{17}$ In addition, fund families with higher expense ratios are more likely to be involved in scandals. Finally, older fund families are less likely to commit scandals, probably because of reputation effects because it takes a long time to build a brand name, and a quality name is critical to selling the funds.

Our analysis of scandal likelihood reveals that unitary boards seem to perform better in preventing fund scandals and that enhancing board independence does not significantly deter trading scandals. We conjecture unitary boards' superior monitoring ability as follows. If fund managers allow market timers to park funds in fund $\mathrm{A}$ in exchange for the opportunity to time fund $\mathrm{B}$ and funds are governed by separate boards, the board of fund B may not detect market-timing activity. However, if both fund A and fund B are overseen by the same board, the chance of detecting and deterring market timing activity is much higher.

\footnotetext{
${ }^{17}$ Another possibility is that only the larger fund families were scrutinized by the SEC. As shown in Zitzewitz (2006), late trading is much more widespread than what is revealed in SEC enforcement actions. Zitzewitz finds late trading in 39 of 60 fund families studied.
} 


\section{Robustness Checks}

Because many sample funds belong to the same fund family and many funds share a single board within a fund family (99 of 126 fund families use unitary boards), sample independence is a legitimate concern. Treating each fund as an independent observation and pooling all funds ignores the commonality across funds within the same family. To control for the family effect, we use a Fama-MacBeth approach following Tufano and Sevick (1997). We group funds based on their investment objectives and perform ordinary least squares regressions within each investment objective group. We then aggregate the coefficients across each group and calculate standard errors. A second approach to alleviate the family effect is to use familylevel data. Relevant data items (size, expense ratios, board size, percentage of independent directors, and director incentives) are aggregated at the family level using individual fund's size as the weight. We repeat all major tests at the family level and the results are generally consistent with our findings at the fund level. As in other prior studies (Tufano and Sevick1997; Del Guercio, Dann, and Partch 2003), lower significance at the family level is observed.

Bank funds are known to use highly independent boards because of a legacy regulation. We control for this bank fund effect by either using a bank fund dummy or excluding bank funds from the sample. Both approaches produce similar results. Several sample funds fall into large fund families such as Fidelity and Vanguard. After excluding these funds from the sample, our findings continue to hold. Busier boards may be less effective monitors (Fich and Shivadasani 2006). After controlling for number of funds overseen by the board, our findings on unitary boards continue to hold. We do not control for residual director compensation. Instead we control for director incentives. Board director turnover is considerably low. Fund fee structure is also stable but the data are readily available in the CRSP database. Assume board structure has not changed from 2002 to 2003 (collecting another year of board data is a formidable task). We use 2002 fund fee, return, and flow data to merge with 2003 board data and repeat all of the tests; the findings on unitary boards is similar. We do not repeat this process for 2004 and 2005 because board structure changed significantly after the passage of the 2004 SEC fund governance regulations.

Overall, augmenting our robustness checks to the consistent results from the previous two sections, we believe our finding that unitary board structure is beneficial to fund shareholders is robust to sample selection and empirical methodology employed.

\section{Conclusion}

Unitary board structure has been widely adopted by many funds today but little research has been done to examine this governance structure. We provide robust 
and consistent results regarding the effectiveness of unitary board structure. Funds with unitary boards charge lower fees, are more likely to share the benefits from economies of scale with fund investors, rank higher on stewardship rating, and have a lower likelihood of committing frauds. Unitary boards are good for two reasons. First, unitary boards facilitate coordination among funds with cost sharing and therefore better capitalize on economies of scale. Second, unitary boards have greater leverage when negotiating with the management company and other service providers. Our empirical evidence indicates that unitary boards better protect shareholder interests and mitigate agency conflicts.

Other governance structures examined include board independence and independent director incentives, in addition to board size. We find that more independent boards do not lower fees and do not carry out the fiduciary function well. The finding regarding director incentive is mixed: it helps lower fees but does not improve regulatory compliance. Larger boards seem to be less effective. Our findings do not provide support for the new SEC rule mandating an independent chairman and at least $75 \%$ independent directors. Rather, we suggest a unitary board with smaller size may be more beneficial to shareholders.

One interesting question is why some fund families use multiple boards. We conjecture the following scenario: When a new fund is opened, fund advisers will consider a new board in two cases: (1) current board is not able to serve the new fund, and (2) past experience with existing board pushes fund advisers to seek new board of director. Both cases indicate an adversarial outcome for fund investors, but from fund adviser's perspective, board structure is endogeneously determined and optimal. Future research on the formation of new fund boards may provide validation for this conjecture.

\section{Appendix}

Morningstar introduced fiduciary grade for mutual funds (which was later renamed stewardship grade) in August 2004. (The first set of grades was released in February 2005.) These grades measure how well the fund managers and fund companies' interests are aligned with fund shareholders' as a result of the board fulfilling its fiduciary duty. They are based on information compiled from public filings, responses to a detailed survey Morningstar sent to each fund company, and the expertise of Morningstar's fund analysts. The data source is for the 3 years leading up to 2003. The overall stewardship grade is determined by five components with their respective detailed aspects:

- Regulatory Issues: Whether the fund has serious breaches of fiduciary duties in the past three years and whether any remedies were in place during such events. 
- Board Quality: (1) Whether the board has taken action in cases where the fund clearly has not served the shareholders well; (2) Do the independent directors have a meaningful investments in the fund? (3) Is the board overseeing too many funds? (4) Does the board meet the maximum SEC requirement for the proportion of independent directors?

- Managerial Incentives: (1) Does the manager have significant investment in the funds overseen, defined as one-third of his or her liquid net worth? (2) Do the compensation plans reward long-term performance or emphasize asset growth?

- Fee Setting: (1) Whether the fund's expense ratio is above or below the average for its type of share class within its peer group defined as its Morningstar category; (2) Whether the fund's expense ratio declined meaningfully as assets grow.

- Corporate Culture: Evaluating a wide range of factors to assess how seriously a firm takes its fiduciary duty to its fund shareholders. Factors considered may include (1) Has the firm launched "trendy" funds in an attempt to gather assets? (2) Has the firm closed funds at an appropriate size? (3) Does the firm implement redemption fees to discourage rapid trading of its funds? (4) Has the firm done a good job of retaining key personnel? (5) How strong are the firm's shareholder communications? (6) Has the firm used soft dollars?

On a scale of 1 to 5 , with 5 being the most desirable, each of the five components is granted a grade, based on the sum of which, an overall stewardship grade is calculated (also on a scale of 1 to 5 ).

\section{References}

Baranchuk, N. and P. Dybvig, Forthcoming, Consensus in diverse corporate boards, Review of Financial Studies.

Barber, B. M., T. Odean, and L. Zheng, 2005, Out of sight, out of mind: The effects of expenses on mutual fund flows, Journal Business 78, 2095-2119.

Blake, C., E. Elton, and M. Gruber, 1993, The performance of bond mutual funds, Journal of Business 66, $370-403$.

Bogle, J. C., 2005, The mutual fund industry 60 year later: For better or worse? Financial Analysts Journal $61,15-24$.

Caillaud, B. and J. Tirole, 2007, Consensus building: How to persuade a group, American Economic Review 97, 1877-1900.

Capon, N., G. J. Fitzsimmons, and R. A. Prince, 1996. An individual level analysis of the mutual fund investment decision, Journal of Financial Services Research 10, 59-82.

Carhart, M., 1997, On persistence in mutual fund performance, Journal of Finance 52, 57-82.

Chen, J., H. Hong, M. Huang, and J. D. Kubik, 2004, Does fund size erode mutual fund performance? The role of liquidity and organization, American Economic Review 94, 1276-1302.

Chen, Q., I. Goldstein, and W. Jiang, Forthcoming, Directors' ownership in the U.S. mutual fund industry, Journal of Finance. 
Chevalier, J. and G. Ellison, 1997, Risk taking by mutual funds as a response to incentives, Journal of Political Economy 105, 1167-1200.

Cooper, M., H. Gulen, and P. R. Rau, 2005, Changing names with style: Mutual fund name changes and their effects on fund flows, Journal of Finance 60, 2825-58.

Cremers, M., J. Driessen, P. Maenhout, and D. Weinbaum, Forthcoming, Does skin in the game matter? Director incentives and governance in the mutual fund industry, Journal of Financial and Quantitative Analysis.

Del Guercio, D., L. Dann, and M. M. Partch, 2003, Governance and boards of directors in closed-end investment companies, Journal of Financial Economics 69, 111-52.

Del Guercio, D. and P. Tkac, 2002, The determinants of the flow of funds of managed portfolios: Mutual funds versus pension funds, Journal of Financial and Quantitative Analysis 37, 523-557.

Ding, B. and R. Wermers, 2006, Mutual fund performance and governance structure: The role of portfolio managers and boards of directors, Working paper, University of Maryland.

Dukes, W. P., P. C. English II, and S. M. Davis, 2006, Mutual fund mortality, 12b-1 fees, and the net expense ratio, Journal of Financial Research 29, 235-52.

Elton, E. J., M. J. Gruber, and J. A. Busse, 2004, Are investors rational? Choices among index funds, Journal of Finance 59, 261-88.

Elton, E. J., M. Gruber, S. Das, and M. Hlavka, 1993, Efficiency with costly information: A reinterpretation of evidence from managed portfolios, Review of Financial Studies 6, 1-22.

Fama, E. F. and M. Jensen,1985, Organizational forms and investment decisions, Journal of Financial Economics 14, 101-19.

Ferris, S. P. and X. (S.) Yan, 2007a, Agency conflicts in delegated portfolio management: Evidence from namesake mutual funds, Journal of Financial Research 30, 473-94.

Ferris, S. P. and X. (S.) Yan, 2007b, Do independent directors and chairmen really matter? The role of boards of directors in mutual fund governance, Journal of Corporate Finance 13, 392-420.

Fich, E. M. and A. Shivdasani, 2006, Are busy boards effective monitors? Journal of Finance 61, 689-724.

Ghosh, C. and C. F. Sirmans, 2003, Board independence, ownership structure and performance: Evidence from real estate investment trusts, Journal of Real Estate Finance and Economics 26, 287-318.

Gruber, M. J., 1996, Another puzzle: The growth in actively managed mutual funds, Journal of Finance 51, 783-810.

Hartzell, J. C., L. Sun, and S. Titman, 2006, The effect of corporate governance on investment: Evidence from real estate investment trusts (REITs), Real Estate Economics 34, 343-76.

Hermalin, B. E. and M. Weisbach, 2003, Board of directors as an endogenously determined institution: A survey of the economic literature, Economic Policy Review, 7-26.

Hermalin, B. E. and M. Weisbach, 2006, A framework for assessing corporate governance reform, Working paper, University of California-Berkeley and University of Illinois at Urbana Champaign.

Investment Company Institute, 2004, The cost of buying and owning mutual funds, Fundamentals: Investment Company Institute Research in Brief 13(1), 1-24.

Jackson, H. and S. Tate, 2000, The role of independent directors in mutual fund governance, Working paper, Harvard Law School.

Johnson, W., 2006, Who monitors the mutual fund manager, new or old shareholders? Working paper, University of Oregon.

Keswani, A. and D. Stolin, 2006, Mutual fund performance persistence and competition: A cross-sector analysis, Journal of Financial Research 29, 349-66.

Khorana, A. and H. Servaes, 2007, Conflicts of interest and competition in the mutual fund industry, Working paper, Georgia Tech and London Business School.

Khorana, A., P. Tufano, and L. Wedge, 2007, Board structure, mergers and shareholder wealth: A study of the mutual fund industry, Journal of Financial Economics 85, 571-98.

Kuhnen, C. M., 2004, Ineffciencies in dynamic contracting in the mutual fund industry, Working paper, Stanford University.

Kuhnen, C. M., 2007, Social networks, corporate governance and contracting in the mutual fund industry, Working paper, Northwestern University.

Lesseig, V. P., D. M. Long, and T. I. Smythe, 2002, Gains to mutual fund sponsors offering multiple share class funds, Journal of Financial Research 25, 81-98. 
Mahoney, P. G., 2004, Manager-investor conflicts in mutual funds, Journal of Economic Perspectives 18, 161-82.

Malhotra, D. and R. MacLeod, 1997, An empirical examination of mutual fund expenses, Journal of Financial Research 20, 175-90.

Meschke, J. F., 2007, An empirical examination of mutual fund boards, Working paper, University of Minnesota.

Qian, M., 2006, Whom can you trust? A study of mutual fund governance, Working paper, National University of Singapore.

Reuter, J. and E. Zitzewitz, 2006, Do ads influence editors? Advertising and bias in the financial media, Quarterly Journal of Economics 121, 197-227.

Sirri, E. R. and P. Tufano, 1998, Costly search and mutual fund flows, Journal of Finance 53, 1589-1622.

Tkac, P. A., 2004, Mutual funds: Temporary problem or permanent morass? Federal Reserve Bank of Atlanta Economic Review, 4th quarter.

Tufano, P. and M. Sevick, 1997, Board structure and fee-setting in the U.S. mutual fund industry, Journal of Financial Economics 46, 321-55.

Varma, R., 2003, An empirical examination of sponsor influence over the board of directors, Financial Review 38, 55-76.

Warner, J. B. and J. S. Wu, 2006, Why do mutual fund advisory contracts change? Fund versus family influences, Working paper, University of Rochester.

Wellman, J. and J. Zhou, 2007, Corporate governance and mutual fund performance: A first look at the Morningstar Stewardship Grades, Working paper, SUNY at Binghamton.

Wermers, R., 2000, Mutual fund performance: An empirical decomposition into stock-picking talent, style, transactions costs, and expenses, Journal of Finance 55, 1655-95.

Zheng, L., 1999, Is money smart? A study of mutual fund investors' fund selection ability, Journal of Finance 54, 901-33.

Zitzewitz, E., 2003, Who cares about shareholders? Arbitrage-proofing mutual funds, Journal of Law, Economics, \& Organization 19, 245-80.

Zitzewitz, E., 2006, How widespread was late trading in mutual funds? American Economic Review Papers \& Proceedings 96(2), 284-89. 